\title{
Spatio-Temporal Variability of Anthropogenic and Natural Wrack Accumulations along the Driftline: Marine Litter Overcomes Wrack in the Northern Sandy Beaches of Portugal
}

\author{
Laura Guerrero-Meseguer 1,2,*(D), Puri Veiga ${ }^{1,2}$ and Marcos Rubal 1,2 (D) \\ 1 Interdisciplinary Centre of Marine and Environmental Research (CIIMAR) of the University of Porto, \\ Novo Edifício do Terminal de Cruzeiros do Porto de Leixões, Avenida General Norton de Matos, \\ 4450-208 Matosinhos, Portugal; puri.sanchez@fc.up.pt (P.V.); marcos.garcia@fc.up.pt (M.R.) \\ 2 Department of Biology, Faculty of Sciences, University of Porto, Rua do Campo Alegre s/n, \\ 4169-007 Porto, Portugal \\ * Correspondence: laura.meseguer@fc.up.pt
}

Received: 4 November 2020; Accepted: 23 November 2020; Published: 26 November 2020

\begin{abstract}
Marine litter can end up deposited on sandy beaches and become entangled in the natural wrack, threatening its roles in ecosystems. However, it is currently unknown whether the storage of both artificial and natural accumulations on sandy beaches is correlated. Here, we quantified and compared, by first time, the litter and natural wrack on five sandy beaches in the north of Portugal. Results showed that the amount of marine litter and natural wrack were not correlated. Most of the sandy beaches had more litter than wrack and both artificial and natural accumulations disclosed high spatio-temporal variability. In summer, annual and opportunistic macroalgae dominated the wrack, while the litter was mainly formed by cigarette butts and leftover food. In winter, perennial taxa were more abundant in the wrack and plastics from mussel farming and cotton bud sticks dominated the litter. The macroalga Fucus spp., plastic pieces and materials from fishing were frequent in both periods. This study confirms that, currently, more litter than natural wrack reaches the Northern Portuguese sandy beaches, evidencing the need to take urgent measures against this contamination. Future management measures should consider this spatio-temporal variability to quantify both depositions.
\end{abstract}

Keywords: macroalgae; seagrasses; litter; plastics; Portuguese coasts; NW Iberian Peninsula; Atlantic Ocean; marine conservation

\section{Introduction}

Large amounts of dislodged macroalgae and seagrasses accumulate on beaches, fulfilling numerous ecological functions [1,2]. Among others, these depositions, known as wrack, protect coasts from erosion, act as refuge for numerous intertidal invertebrates and are sources of food and nutrients for marine ecosystems $[3,4]$. However, nowadays, macroalgae and seagrasses are not the only items that end up accumulated on sandy beaches. In recent decades, high amounts of marine litter are deposited on the sand, becoming entangled in the natural wrack and altering its services to nearby ecosystems $[5,6]$. However, up to now, just one study has assessed both artificial and natural accumulations on sandy beaches [5].

Marine litter can be indirectly introduced on beaches by rivers, storms, winds, or sewages systems, but it can also be directly deposited by tourism, fishing, or recreational activities [7]. Most of the litter that arrives to the shorelines is plastic and is mainly deposited on the beaches close to population 
centres, but it also occurs in more remote areas [8-11]. Besides plastics, other materials such as wood, metals, glass, rubber, clothing or paper also frequently accumulated on the coasts. Marine litter can be deposited upon the seabed or can be incorporated and trapped under the sand, which complicates its quantification and removal $[12,13]$. This litter can also become entangled in fauna and flora or can be ingested by marine organisms [14,15]. Marine litter is also transported by ocean currents for substantial periods of time therefore increasing the potential for invasions of alien species, which is one of the major threats of coastal ecosystems [16].

In addition to environmental impacts, marine litter can negatively influence beach aesthetic and increases pollution, affecting humans at economic, social, and health levels $[17,18]$. Such is the concern for this type of pollution that the United Nations urges to prevent and reduce marine litter by 2025 (Target 14.1) as part of the Decade of Ocean Science for Sustainable Development (2021-2030). In this framework, the monitoring and quantification of marine litter is essential to determine the baseline data in the environment, to adopt effective management and mitigation measures along the coasts and to evaluate the main sources and activities which are causing this problem [19]. This information allows us to detect future changes in the quantity of marine litter, determining a 'standing stock' that can help political and management interventions [20].

The proximity of the source of marine litter, local hydrodynamics, social and economic factors (i.e., policy, education, tourism or other anthropogenic activities), can influence the accumulation of marine litter on beaches [21-23]. Since environmental conditions and anthropogenic activities, such as fishing and tourism, often occur seasonally, the accumulation of marine litter can also vary over time. Similarly, natural wrack deposits on beaches are extremely variable around the world (i.e., [3,24-27]). Natural wrack accumulations can be influenced by the physical environment and oceanographic conditions that promote wrack arrival near coasts and upon beaches [28], but also by the life cycles, composition, and buoyancy of the species that compose it $[29,30]$. Therefore, a sampling design that simultaneously includes the quantification of marine litter and wrack and their spatio-temporal variability could provide us useful information on the ecological status of the beaches and the potential relationship between both artificial and natural accumulations.

The objective of this study is to determine the composition and abundance of natural wrack and marine litter of five sandy beaches in the north of Portugal in two different dates to know their spatio-temporal variability and to explore a potential correlation between both artificial and natural accumulations. To do this, accumulations of natural wrack and marine litter were collected, identified, counted, and weighted across two different seasons to identify their spatio-temporal variability.

\section{Materials and Methods}

\subsection{Study Area}

Natural wrack and marine litter accumulations were collected on five beaches in northern Portugal during the summer and winter of 2019-2020 (Figure 1). These five beaches were selected based on criteria proposed by OSPAR, (2010) [31]: they were composed of sand, exposed to the open sea, accessible all the year, measured between $100 \mathrm{~m}$ and $1 \mathrm{~km}$ of length, were free of any constructed buildings and, to our knowledge, they were not subjected to any other litter collection activities. All the beaches were orientated to the westerly direction.

Before each sampling, beach slope was determined by Emery's profiling technique [32]. Beaches showed different profiles between summer and winter (Figure S1). In summer, the beaches accumulated sediment on the foreshore, shortening the distance between the step and the berm of the beaches. However, in winter, the berms were eroded and decreased in height, forming beaches with a steeper slope and less undulation than during summer, except in Cabedelo, whose slope was more pronounced in summer (Figure S1). Sediments were predominantly composed by medium and coarse sand ranging between moderately well sorted and very well sorted (Table S1). 


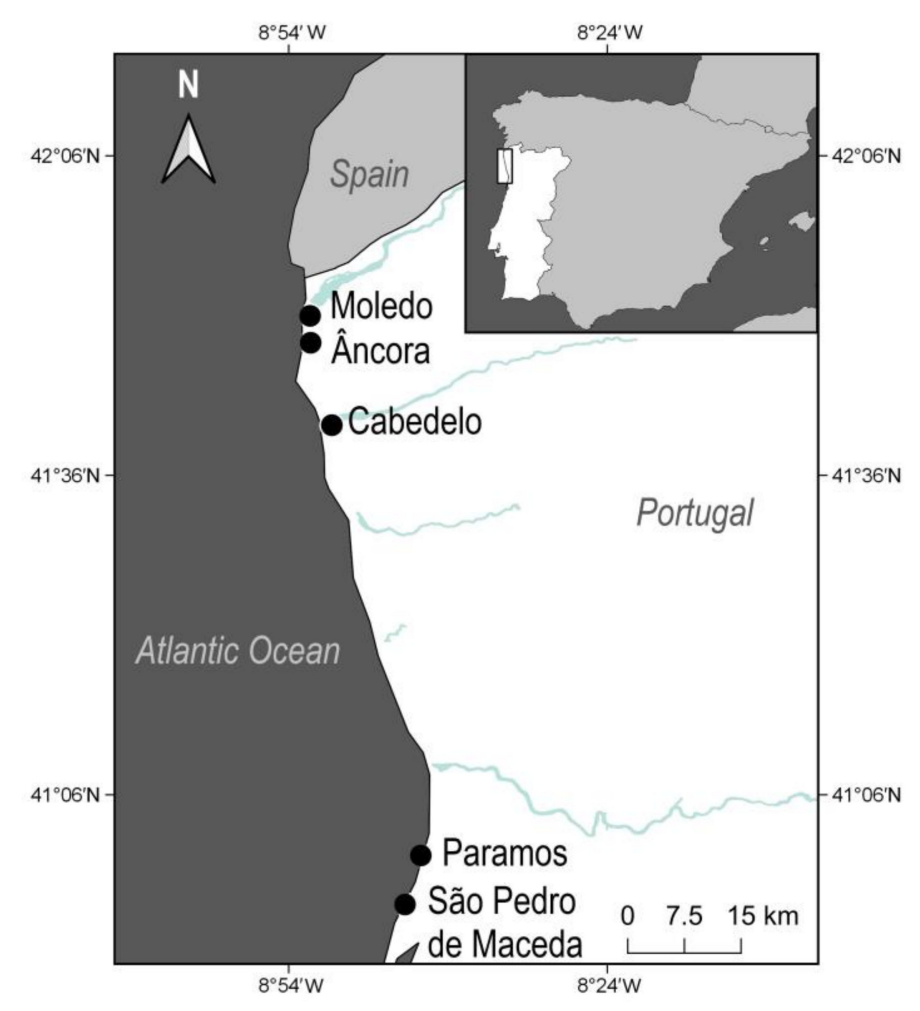

Figure 1. Map of the north Portuguese coast showing location of the five studied beaches for the surveys of marine litter and natural wrack.

\subsection{Collection of Marine Litter and Natural Wrack}

Natural wrack and marine litter (both of $>5 \mathrm{~mm}$ in size) were collected along three random transects parallel to the coast line $(33.3 \mathrm{~m})$ from the low tide water level to the backshore, making a total of $100 \mathrm{~m}$ of length on each beach. Transect width was about $50 \mathrm{~m}$. Collections were done during low tide periods. The litter and natural wrack of each transect and beach was separated into bags and transported to the laboratory, where it was cleaned, classified and dried at $60^{\circ} \mathrm{C}$ until it lost all the water content (in the case of litter) or reached a constant weight (in the case of natural wrack). Heat-sensitive materials of litter were dried in the open air.

Marine litter was classified following the OSPAR (2010) recommendations for surveys of $100 \mathrm{~m}$ transect [31]. The natural wrack of each transect was classified to species level where possible, but many of the macrophytes were degraded, so in those cases they were identified to the lowest taxonomic level possible. Additionally, the percentage of the wrack and marine litter were calculated per transect within each beach. To do this, the percent contribution of each litter material according to OSPAR (2010) (i.e., plastic/polystyrene, rubber, cloth, paper/cardboard, wood, metal, glass, pottery/ceramics, sanitary waste, medical waste, feces, and other pollutants) [31] and major wrack taxa (i.e., Seagrasses, Heterokontophyta, Rhodophyta, and Chlorophyta) were determined.

\subsection{Data Analyses}

Marine litter and natural wrack data were analysed using univariate and multivariate techniques to test if examined response variables differed across the studied sandy beaches (i.e., spatial variability) on the two sampled dates (i.e., temporal variability). For marine litter, univariate analyses of variance (ANOVA) tests were used to identify the significant differences on the percentage contribution of marine litter materials, number of litter items, litter weight and marine litter diversity based on OSPAR categories. For natural wrack, significant differences on the percentage contribution of the major taxa, total biomass and natural wrack diversity, were also explored with ANOVA. These analyses were based 
on a two-way model with Beach as an orthogonal fixed factor with five levels (i.e., Moledo, Âncora, Cabedelo, Paramos and São Pedro de Maceda) and Date as an orthogonal random factor with two levels (date 1 in summer and date 2 in winter). Cochran's $C$ tests were previously done to check for homogeneity of variances, and when tests were significant $(p<0.05)$, data were transformed to remove the heterogeneity. When data did not meet the assumptions of homogeneity, untransformed data were left but applying a stricter significance level of $p<0.01$ [33]. Whenever ANOVA showed significant differences, a post-hoc Student-Newman-Keuls (SNK) test was done to explore the differences among all pairs of levels of the term of interest.

Permutational multivariate analysis of variance (PERMANOVA) [34] based on untransformed data using Bray-Curtis similarities to explore differences on the multivariate data of the assemblages of natural wrack biomass and marine litter (i.e., based on the weight and on the number of items of the OSPAR categories). The experimental design of the PERMANOVA was the same as the aforementioned for the ANOVA analyses. When PERMANOVA showed significant differences $(P<0.05)$, a pair-wise comparison (999 permutations) was done to explore the differences among all pairs of levels of the selected factor. To test whether differences between beaches and dates were due to different multivariate dispersion among groups rather than in the location of centroids, the PERMDISP procedure was done [35]. Multivariate patterns were illustrated by non-metric multidimensional scaling (nMDS) ordination.

The SIMPER procedure [36] was used to determine the percentage contribution ( $\delta \mathrm{i} \%$ ) of the different taxa or OSPAR categories which composed the natural wrack and marine litter across beaches and dates to the Bray-Curtis dissimilarity $(\delta \mathrm{i})$. A wrack taxa or OSPAR category of marine litter was considered important if its contribution to total percentage of dissimilarity was $\geq 3 \%$. The $\delta \mathrm{i} / \mathrm{SD}(\delta \mathrm{i})$ ratio was used to quantify the consistency of the contribution of a particular wrack taxa or OSPAR category to the average dissimilarity in all pair-wise comparisons of samples across beaches and dates. Values $\geq 1$ indicated a high degree of consistency and thus a reliable indicator of wrack or litter accumulations. Finally, to analyse the possible correlation between the natural wrack biomass and marine litter weight and between the number of marine litter items and their weight, similitude between the correlation matrixes based on the previous pairs of variables were analysed using the RELATE function $[37,38]$.

\section{Results}

\subsection{Composition and Quantification of the Natural Wrack}

No significant differences across beaches and dates were detected for major taxa (Table S2). However, ANOVA analyses showed significant differences in the total biomass and diversity of the natural wrack for the interaction between the factors beach and date (Table 1). In summer, the total biomass of natural wrack on the five study beaches was double of that found in winter (Figure 2A). Nevertheless, there was a large amount of variation between beaches and dates in the biomass and diversity of wrack taxa (Figure 3A,B). For the summer date only Moledo had significantly greater values than the rest of the beaches but in winter, Cabedelo had significantly greater values of wrack biomass (Figure 3A). In summer, Moledo had significantly greater diversity of wrack, while in winter, no significant differences were detected among beaches (Figure 3B).

PERMANOVA analyses also showed a significant interaction between the factors beach and date for the structure of the natural wrack assemblage (Tables 2 and 3, Figure 4A). PERMDISP analyses showed that these differences were due to the distance of the centroids rather than data dispersion $\left(\mathrm{F}_{9,20}=4.21 ; P=0.239\right)$. In summer, the structure of natural wrack assemblage in Modelo was significantly different to the remaining beaches, mainly because of the greater abundance of Saccorhiza polyschides (Lightfoot) Batters 1902 (Table 3 and Table S3, Figure 5A). Moreover, the natural wrack assemblage of Cabedelo was also significantly different to that of São Pedro de Maceda, because of greater abundance of Fucus spp. (Table 3 and Table S3, Figure 5A). In winter, the natural wrack 
assemblage was very variable among beaches (Table 3, Figure 5A). The main taxa responsible for these differences were Fucus spp. (with high abundance in Cabedelo) and Ascophyllum nodosum (Linnaeus) Le Jolis 1863 (more abundant in Âncora than in Paramos; Table S3).

Table 1. Results of the two-way ANOVA analyses of the effects of the beach (Moledo, Âncora, Cabedelo, Paramos and São Pedro de Maceda) and date of collection (summer and winter) on biomass and diversity of natural wrack and on the diversity of OSPAR categories, weight and number of items of marine litter. Significant differences among treatments are highlighted in bold $(p<0.01)$.

\begin{tabular}{|c|c|c|c|c|c|}
\hline \multirow{2}{*}{ Variable } & \multicolumn{5}{|c|}{ Two-Way ANOVA } \\
\hline & $\begin{array}{l}\text { Source of } \\
\text { Variation }\end{array}$ & DF & MS & $\mathbf{F}$ & $p$-Value \\
\hline Natural Wrack Biomass & Beach (B) & 4 & 8.315 & 1.2 & 0.433 \\
\hline \multirow[t]{3}{*}{${ }^{*} \operatorname{Ln}(x+1)$ transformed } & Date (D) & 1 & 29.4 & 46.75 & 0.001 \\
\hline & $\mathrm{B} \times \mathrm{D}$ & 4 & 6.954 & 11.06 & 0.001 \\
\hline & Residual & 20 & 0.629 & & \\
\hline \multirow[t]{4}{*}{ Natural Wrack Diversity } & Beach (B) & 4 & 38.03 & 0.41 & 0.793 \\
\hline & Date (D) & 1 & 496.1 & 58.6 & 0.001 \\
\hline & $\mathrm{B} \times \mathrm{D}$ & 4 & 91.97 & 10.86 & 0.001 \\
\hline & Residual & 20 & 8.467 & & \\
\hline \multirow[t]{4}{*}{ Marine Litter Diversity } & Beach (B) & 4 & 222.5 & 1.56 & 0.339 \\
\hline & Date (D) & 1 & 0 & 0 & $\mathrm{~F}=0$ \\
\hline & $\mathrm{B} \times \mathrm{D}$ & 4 & 142.8 & 8.69 & 0.001 \\
\hline & Residual & 20 & 16.43 & & \\
\hline Weight of Marine Litter & Beach (B) & 4 & 9.538 & 1.73 & 0.305 \\
\hline \multirow[t]{3}{*}{${ }^{*} \operatorname{Ln}(x)$ transformed } & Date (D) & 1 & 3.053 & 2.24 & 0.15 \\
\hline & $\mathrm{B} \times \mathrm{D}$ & 4 & 5.518 & 4.05 & 0.015 \\
\hline & Residual & 20 & 1.363 & & \\
\hline No. of Items of Marine Litter & Beach (B) & 4 & 8.317 & 2 & 0.259 \\
\hline \multirow[t]{3}{*}{${ }^{*} \operatorname{Ln}(x)$ transformed } & Date (D) & 1 & 1.835 & 8.77 & 0.008 \\
\hline & $\mathrm{B} \times \mathrm{D}$ & 4 & 4.155 & 19.85 & 0.001 \\
\hline & Residual & 20 & 0.209 & & \\
\hline
\end{tabular}

A

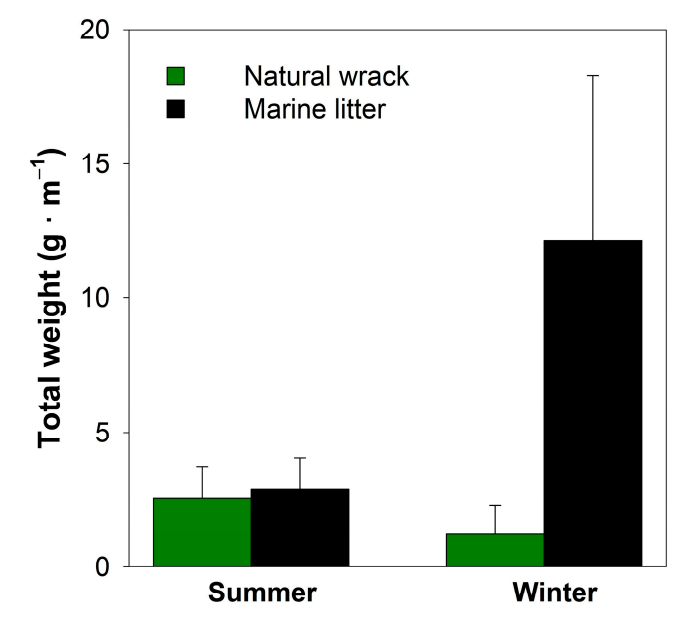

B

\section{Total weight $(\%)$}

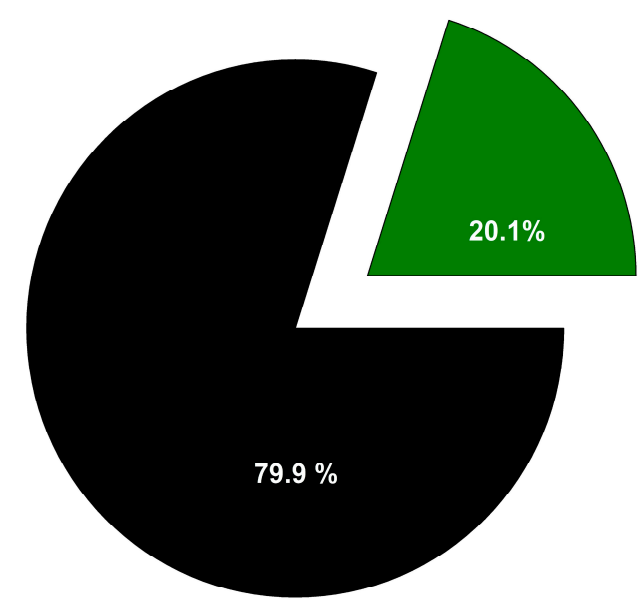

Figure 2. Average of the total weight of natural wrack and marine litter per date (A) (mean $\pm \mathrm{SE} ; n=5)$ and percentage of natural wrack (green) and marine litter (black) with respect to the overall weight of both accumulations over the study period (B). 
A

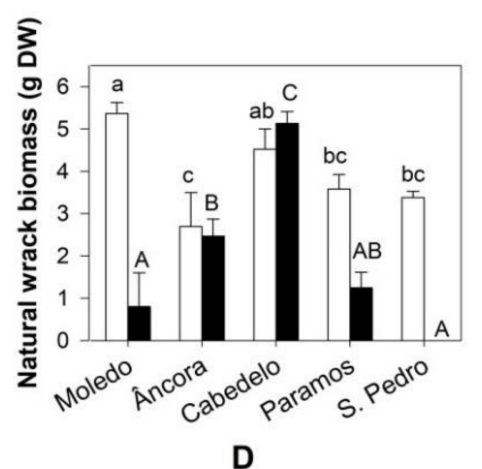

D

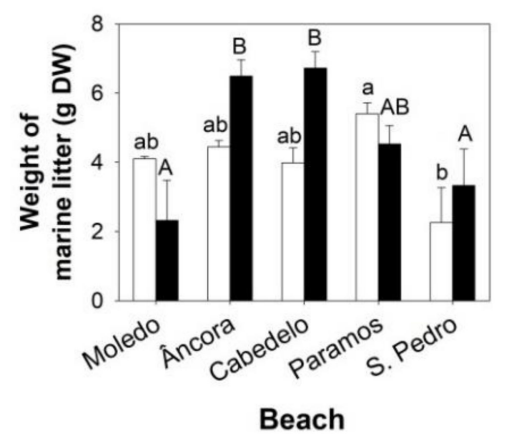

B

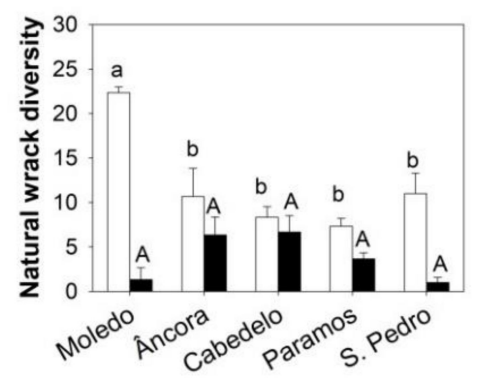

E

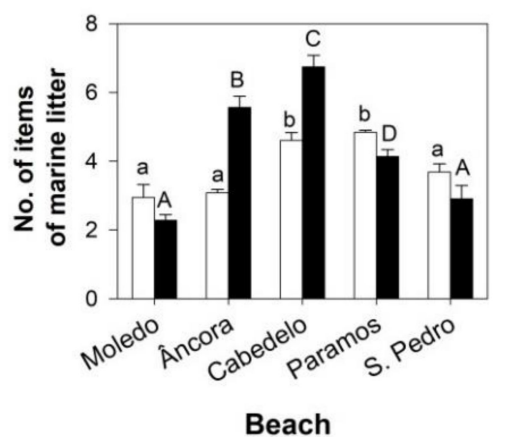

Figure 3. Averages per transect (mean $+\mathrm{SE}$ ) of the total biomass of the natural wrack (A), natural wrack diversity (B), marine litter diversity (C), weight (D) and number of items (E) of marine litter on each beach in the North of Portugal in summer of 2019 (white) and in winter of 2020 (black). Natural wrack biomass were $\operatorname{Ln}(x+1)$ transformed and weight and items of marine litter were transformed to $\operatorname{Ln}(x)$. Different letters indicate significant differences $(p<0.01)$ among beaches in summer (lowercase letters) and winter (capital letters).

Table 2. PERMANOVA results of the effects of the beach (Moledo, Âncora, Cabedelo, Paramos and São Pedro de Maceda) and dates (summer and winter) on the multivariate data of natural wrack assemblages (based on taxa biomass) and assemblages of marine litter based on weight and items of OSPAR categories. Significant differences are highlighted in bold $(p<0.01)$.

\begin{tabular}{cccccccccccc}
\hline & & \multicolumn{3}{c}{$\begin{array}{c}\text { Natural Wrack } \\
\text { Assemblage }\end{array}$} & \multicolumn{4}{c}{$\begin{array}{c}\text { Marine Litter Assemblage } \\
\text { Based on Weight }\end{array}$} & \multicolumn{3}{c}{$\begin{array}{c}\text { Marine Litter Assemblage } \\
\text { Based on Items }\end{array}$} \\
\cline { 3 - 11 } $\begin{array}{c}\text { Source of } \\
\text { Variation }\end{array}$ & d.f. & MS & $\boldsymbol{F}$ & $\boldsymbol{P}$ & MS & $\boldsymbol{F}$ & $\boldsymbol{P}$ & MS & $\boldsymbol{F}$ & $\boldsymbol{P}$ \\
\hline Beach (B) & 4 & 9156 & 1.59 & 0.114 & 6301 & 1.26 & 0.212 & 7464 & 1.29 & 0.266 \\
Date (D) & 1 & 17,574 & 14.77 & $\mathbf{0 . 0 0 1}$ & 7280 & 2.44 & $\mathbf{0 . 0 0 4}$ & 11,369 & 8.91 & $\mathbf{0 . 0 0 1}$ \\
B $\times$ D & 4 & 5771 & 4.85 & $\mathbf{0 . 0 0 1}$ & 5017 & 1.68 & $\mathbf{0 . 0 0 2}$ & 5797.9 & 4.55 & $\mathbf{0 . 0 0 1}$ \\
Residual & 20 & 1190 & & & 2985 & & & 1275.7 & & \\
\hline
\end{tabular}


Table 3. Multivariate pair-wise comparison of wrack assemblages and marine litter for the term Beach $\times$ Date. Significant differences are highlighted in bold $(p<0.01)$.

\begin{tabular}{|c|c|c|c|c|c|c|c|}
\hline Variable & Date & Beach & Moledo & Âncora & Cabedelo & Paramos & $\begin{array}{l}\text { São Pedro } \\
\text { de Maceda }\end{array}$ \\
\hline \multirow{10}{*}{$\begin{array}{l}\text { Assemblage of } \\
\text { natural wrack } \\
\text { biomass }\end{array}$} & \multirow{5}{*}{ Summer } & Moledo & \multirow[t]{5}{*}{1} & 0.035 & 0.008 & 0.004 & 0.003 \\
\hline & & Âncora & & \multirow[t]{4}{*}{1} & 0.06 & 0.128 & 0.095 \\
\hline & & Cabedelo & & & \multirow[t]{3}{*}{1} & 0.051 & 0.018 \\
\hline & & Paramos & & & & \multirow[t]{2}{*}{1} & 0.237 \\
\hline & & São Pedro de Maceda & & & & & 1 \\
\hline & \multirow{5}{*}{ Winter } & Moledo & \multirow[t]{5}{*}{1} & 0.041 & 0.014 & 0.167 & 0.363 \\
\hline & & Âncora & & \multirow[t]{4}{*}{1} & 0.007 & 0.113 & 0.002 \\
\hline & & Cabedelo & & & 1 & 0.001 & 0.001 \\
\hline & & Paramos & & & & 1 & 0.028 \\
\hline & & São Pedro de Maceda & & & & & 1 \\
\hline \multirow{10}{*}{$\begin{array}{l}\text { Assemblage of } \\
\text { marine litter } \\
\text { based on } \\
\text { weight }\end{array}$} & \multirow{5}{*}{ Summer } & Moledo & \multirow[t]{5}{*}{1} & 0.383 & 0.138 & 0.099 & 0.271 \\
\hline & & Âncora & & \multirow[t]{4}{*}{1} & 0.125 & 0.08 & 0.268 \\
\hline & & Cabedelo & & & \multirow{3}{*}{1} & 0.038 & 0.177 \\
\hline & & Paramos & & & & \multirow[t]{2}{*}{1} & 0.046 \\
\hline & & São Pedro de Maceda & & & & & 1 \\
\hline & \multirow{5}{*}{ Winter } & Moledo & \multirow[t]{5}{*}{1} & 0.051 & 0.042 & 0.081 & 0.153 \\
\hline & & Âncora & & \multirow[t]{4}{*}{1} & 0.33 & 0.091 & 0.038 \\
\hline & & Cabedelo & & & \multirow{3}{*}{$\begin{array}{c}0.33 \\
1\end{array}$} & 0.05 & 0.021 \\
\hline & & Paramos & & & & 1 & 0.147 \\
\hline & & São Pedro de Maceda & & & & & 1 \\
\hline \multirow{7}{*}{$\begin{array}{l}\text { Assemblage of } \\
\text { marine litter } \\
\text { based on items }\end{array}$} & \multirow{5}{*}{ Summer } & Moledo & \multirow[t]{5}{*}{1} & 0.25 & 0.098 & 0.057 & 0.205 \\
\hline & & Âncora & & \multirow[t]{4}{*}{1} & 0.008 & 0.005 & 0.041 \\
\hline & & Cabedelo & & & \multirow[t]{3}{*}{1} & 0.087 & 0.032 \\
\hline & & Paramos & & & & 1 & 0.027 \\
\hline & & São Pedro de Maceda & & & & & 1 \\
\hline & \multirow{2}{*}{ Winter } & Moledo & \multirow[t]{2}{*}{1} & 0.009 & 0.006 & 0.015 & 0.035 \\
\hline & & Âncora & & 1 & 0.049 & 0.036 & 0.004 \\
\hline
\end{tabular}

A

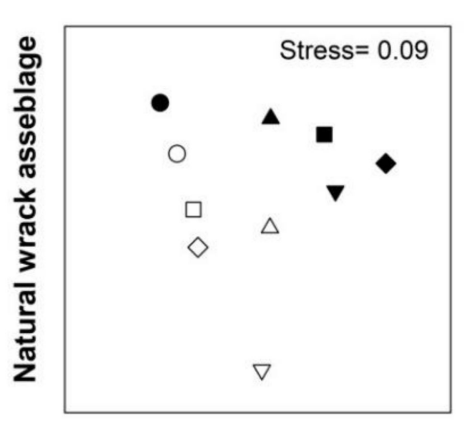

B

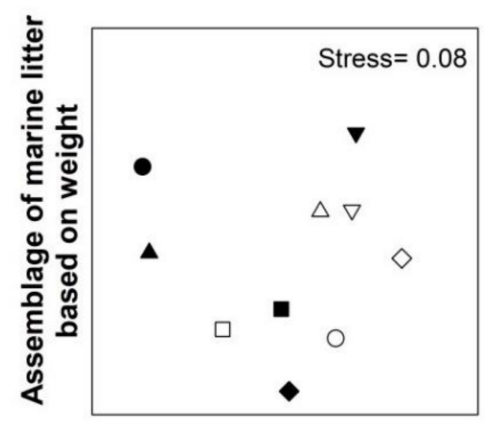

C

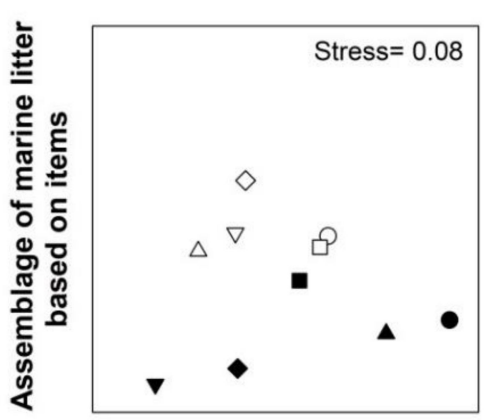

Figure 4. Non-metric multidimensional scaling ordination (nMDS) averaged per beach and by date of the natural wrack assemblage based on species' biomasses (A) and assemblages of marine litter based on weight (B) and items (C) obtained per transect on each beach of the North of Portugal in the summer of 2019 (white) and in the winter of 2020 (black). Âncora (upward triangles), Moledo (downward triangles), Cabedelo (circles), Paramos (squares) and São Pedro de Maceda (rhombuses). 
A

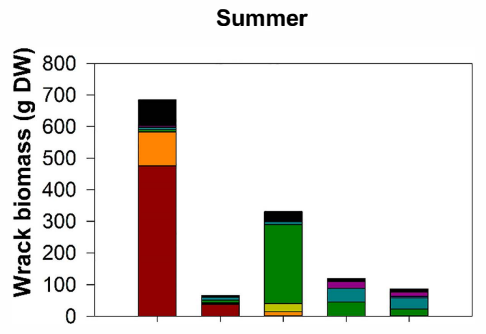

B

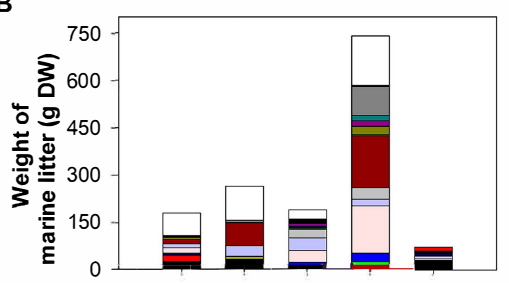

C

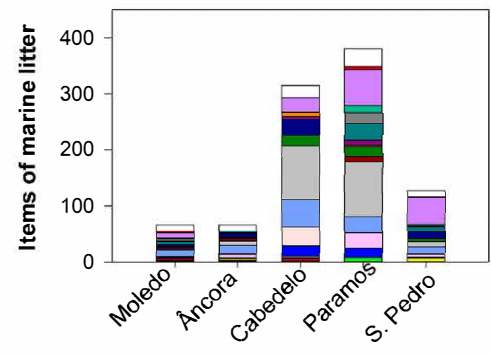

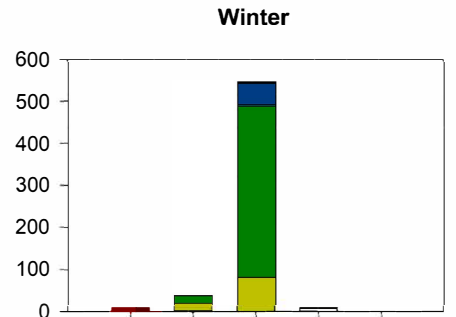
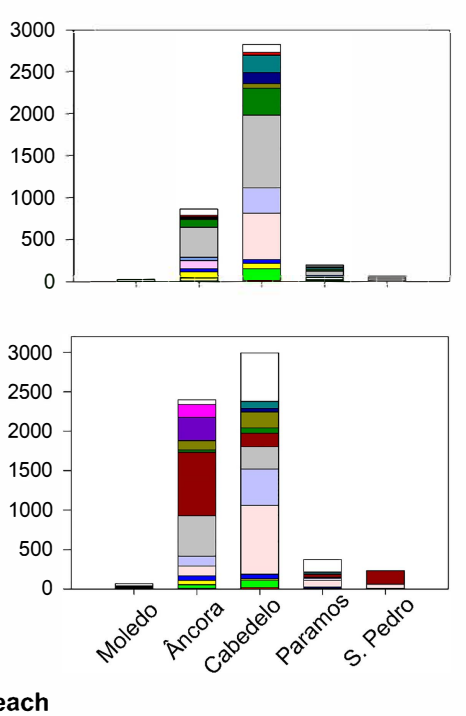

Natural wrack taxa

Saccorhiza polyschides

Ulva sp.

Ascophyllum nodosum

Fucus $s p$.

Sargassum muticum

Cystoseira sp.

Himanthalia elongata

Himanthalia

Marine litter OSPAR categories

Other (Pollutants)

Food containers incl. fast food containers

Foam sponge

Other plastic/polystyrene items

Caps/lids

Plastic/polystyrene pieces $2.5-50 \mathrm{~cm}$

String and cord (diameter less than $1 \mathrm{~cm}$ )

Plastic/Polystyrene pieces $0-2.5 \mathrm{~cm}$

Rope (diameter more than $1 \mathrm{~cm}$ )

Cotton bud sticks

Oyster nets or mussel bags incl. plastic sticks

Cigarette butts

Sanitary towels/panty liners/baking strips

Industrial packaging, plastic sheeting

Tangled net/cord/rope and string

Clothing

Nets and pieces of net $<50 \mathrm{~cm}$

Drinks (bottles, containers and drums)

Strapping bands

Fishing line (angling)

Crisp/sweet packets and lolly sticks

Other sanitary items

Other OSPAR categories (i.e., straws, bags)

Figure 5. Total biomass and main taxa which composed the natural wrack classified at the lower level of aggregation (A) and weight (B) and number of items $(\mathbf{C})$ of the main OSPAR categories which formed the marine litter on each beach of the North of Portugal in the summer of 2019 and in the winter of 2020.

\subsection{Marine Litter}

\subsubsection{Percentage of Abundance of the Marine Litter Materials and Diversity of OSPAR Categories}

The percentages of abundance of the marine litter materials did not show significant differences in both dates and beaches (Table S2). The most abundant material was 'plastic/polystyrene', the second was 'sanitary waste' and the third was 'paper/cardboard'. However, the diversity of OSPAR categories included in the marine litter showed significant differences for the interaction of both tested factors (Table 1, Figure 3C). In summer, Paramos and São Pedro de Maceda had significantly greater diversity of OSPAR categories than Âncora and Moledo, but similar values when compared to Cabedelo (Figure 3C). In winter, the beaches that showed the highest diversity of OSPAR categories were Cabedelo and Âncora. Moreover, the beach of Paramos showed significantly greater diversity of OSPAR categories than São Pedro de Maceda (Figure 3C).

\subsubsection{Weight of Marine Litter}

In winter, the total weight of marine litter was four times greater than in summer (Figure 2A). The weight of marine litter per transect showed significant differences for the interaction of both tested factors (Table 1). In summer, Paramos significantly exceeded the litter weight of São Pedro de Maceda, but obtained similar values to the rest of the beaches (Figure 3D). In winter, the weight of the marine litter of Cabedelo and Âncora was significantly greater than in Moledo and São Pedro de Maceda, but similar to Paramos (Table 1, Figure 3D).

The PERMANOVA analyses showed a significant interaction between beach and date for the assemblage of marine litter based on weight (Tables 2 and 3, Figure 4B). PERMDISP analyses showed that these differences were due to the distance of the centroids rather than data dispersion $\left(\mathrm{F}_{9,20}=4.8\right.$; 
$P=0.1$ ). During the summer, the structure of the assemblage of marine litter based on weight was very variable among beaches, especially in Paramos, Cabedelo and São Pedro de Maceda (Table 3). The differences among these three beaches were mainly due to a greater weight of the OSPAR categories 'rope (diameter more than $1 \mathrm{~cm}$ )', 'plastic/polystyrene pieces $2.5-50 \mathrm{~cm}^{\prime}$ and 'tangled net/cord/rope and string' in Paramos compared with the other beaches (Figure 5B, Table S3). In winter, the structure of the assemblage of marine litter based on weight also was very variable among beaches (Table 3). This variability was mainly caused by a greater weight in Cabedelo than in Moledo and São Pedro de

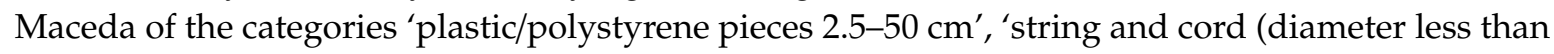
$1 \mathrm{~cm}$ )' and 'plastic/polystyrene pieces $0-2.5 \mathrm{~cm}$ ' (Figure 5B, Table S3).

The proportion of marine litter collected throughout the study was almost four times higher than that of natural wrack (Figure 2B) but the weight of marine litter did not show any significant correlation with the total biomass of natural wrack $(p=0.07$; rho $=0.11)$. The total amount of marine litter collected in summer weighted slightly more than the total amount of natural wrack, but some of the beaches accumulated more wrack than litter in summer (Figure 2A, Figure 5A,B). In contrast, in winter, all the studied beaches accumulated more weight of marine litter than of natural wrack (Figure 2A, Figure 5A,B).

\subsubsection{Items of Marine Litter}

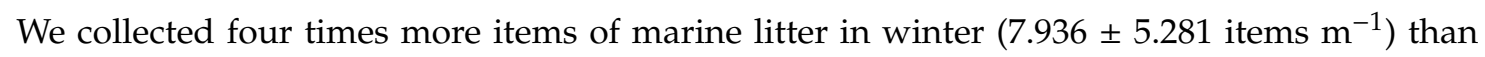
in summer $\left(1.910 \pm 0.659\right.$ items $\left.\mathrm{m}^{-1}\right)$. The number of litter items per transect showed significant differences for the interaction between beach and date (Table 1). In summer, Paramos and Cabedelo showed a significantly greater number of items than the remaining beaches but in winter, Cabedelo showed the highest number of litter items (Table 1, Figure 3E).

The PERMANOVA analyses showed a significant interaction between beaches and dates for the assemblage of marine litter based on items (Tables 2 and 3, Figure 4C). PERMDISP analyses showed that these differences were due to the distance of the centroids not due to data dispersion $\left(\mathrm{F}_{9,20}=3.65 ; P=0.35\right)$. In summer, the structure of the assemblage of marine litter based on items found in Âncora was significantly different to that obtained in São Pedro de Maceda, Paramos and Cabedelo (Table 3; Figure 5C). These differences were mainly due to Âncora showed a lower number of items of the categories 'plastic/polystyrene pieces $0-2.5 \mathrm{~cm}^{\prime}$, 'string and cord (diameter less than $1 \mathrm{~cm}$ )' and 'fishing line (angling)' than Cabedelo and Paramos (Table S3, Figure 5C). In winter, Moledo showed a lower number of items for all the OSPAR categories than the rest of the beaches (Table S3; Figure $5 \mathrm{C}$ ). The assemblage of marine litter based on weight was significantly positively correlated with the assemblage of marine litter based on the number of items $(p=0.001$, rho $=0.611)$.

\section{Discussion}

This study demonstrated that the quantity of marine litter that reaches the northern sandy beaches of Portugal is much greater than the amount of natural wrack that accumulates on the shoreline. Both natural wrack and marine litter accumulations had high variation that depended on the particular beach sampled. Although natural wrack depositions were greater in summer, the accumulation of marine litter was more intensive in winter. However, some beaches showed the inverse trend. These results indicate that, as well as other factors such as meteorological conditions and natural life cycle of the wrack species, the geomorphodynamics of the beaches could play an important role in the storage of marine litter and natural wrack on sandy beaches.

During the summer, the beaches of the north of Portugal suffer sedimentation and the sand end up accumulating along the foreshore as a high berm (as shown in Figure S1). Contrarily, in winter, erosion due to waves and adverse meteorological conditions flatten the berm of the sandy beaches. These morphodynamic changes could result in natural and anthropogenic materials that are deposited on the beaches remaining buried under the sand in summer, and in winter, they being uncovered due to erosion. While the natural wrack degrades over time [30,39], marine litter can persist intact under 
the sand for months or years $[9,40]$ which could explain the highest amount of litter obtained in our study during the winter. This matches with the results obtained in previous studies from the North Atlantic, in which marine litter accumulations were also greater in the winter months [41,42]. Moreover, the presence of macroalgal species in the natural wrack of the winter that are usually frequent during the summer (i.e., S. polychisdes) reinforces our explanation that the beach morphodynamics could play an important role in the accumulation of both depositions. Nevertheless, the biomass of the natural wrack and the weight of marine litter were not statistically correlated in our study, which suggests different mechanisms of accumulation for these kinds of depositions on sandy beaches (e.g., temporal differences in the supply dynamics, different depositional behaviour).

Other factors, such as recruitment strategies of the taxa found within the wrack, could also influence the accumulation on sandy beaches. For instance, S. polyschides was one of the most abundant species of the natural wrack in summer, together with the biennial Himanthalia elongata (Linnaeus) S.F. Gray 1821, the pseudoperennial Sargassum muticum (Yendo) Fensholt 1955 or the opportunistic Ulva spp. These macroalgal taxa are characterized by having sustained active growth in spring and summer, reaching maximal size and reproductive stage very quickly during these periods [27,43-48]. This greater biological development during summer means that the reproductive or vegetative branches of these species may be detached by waves and currents, then accumulating in the natural wrack. Nevertheless, after the summer, these macroalgal species usually decay as it is an unfavourable period in terms of nutrition so they cannot cope with that level of extensive growth over the long-term [49]. In contrast, perennial macroalgae are slow-growth species which develop large nutrient stored pools during the winter, allowing them to survive better in the winter months [47,49]. This explains the dominance of Fucus spp. A. nodosum and Cystoseira spp. in the natural wrack during the winter in our study.

In concordance with previous studies, our results showed a high temporal and spatial variability in the diversity and quantity of natural wrack on sandy beaches [4,30,50-52]. No study was found in the literature that allowed us to compare the composition of natural wrack taxa in our study with other Portuguese beaches. However, our results coincide with other studies in Galician beaches, which obtained a similar number of taxa annually and also showed high abundance of the taxa S. polyschides, Fucus spp., S. muticum and Ulva spp. [50,53]. Despite the fact that the quantity of natural wrack per beach in the North of Portugal was generally much lower than those found in Galicia, the taxa Fucus spp., S. polyschides and A. nodosum were more abundant in the north of Portugal. In addition to recruitment strategies, morphological adaptations of the natural wrack species can also influence such spatio-temporal variability. For instance, the drifting of the invasive alga S. muticum increases in spring and summer, when it is also more abundant in the natural wrack [50]. This is due to this species self-thins to be dispersed to complete its life cycle [54]. Moreover, species with air bladders in their structures, such as Fucus spp., A. nodosum and Cystoseira spp., are more frequently found in the wrack after periods of high wave exposure [50], such as that occurred during the winter in our study. As these species were especially abundant in Cabedelo's beach in winter, we could speculate that the largest amount of wrack and marine litter on this beach could be intensified by adverse meteorological conditions prior to sampling. This could also explain the greater amount of marine litter found in winter in comparison with summer.

In the sandy beaches of northern Portugal, the total weight of marine litter was four times greater than the total weight of natural wrack, especially during winter. Coinciding with other studies, the most abundant material of the marine litter was plastic [41,42,55-57]. Most of this plastic originated from fishing materials such as ropes, tangled nets, cords or strings, fishing lines or plastic stoppers for mussel farming, which could be harmful to marine organisms [58-60]. Small plastic pieces were also very numerous, which probably came from the breakdown or degradation of larger plastic debris items because of the wave action or physical abrasion $[9,61]$. Industrial packaging or plastic sheeting and other plastic instruments used for human sanitary purposes, such as cotton bud sticks, were especially abundant in our study during the winter. Such type of plastic materials have great buoyancy, so they 
can be easily washed away by runoffs from rivers to the sea after periods of heavy rains, which would explain their greatest proportion in winter. In winter, in Cabedelo the number of cotton bud sticks increased among other items. Similarly, in Âncora, the quantity of cotton bud sticks increased in winter, but in the rest of the beaches was similar in both periods. During the winter, the rivers of the north of Portugal have large volume discharges of water to coastlines because of heavy storms, which could also cause the inefficiency of sewage treatment plants and wastewater problems, promoting the direct discharge of sanitary items such as cotton bud sticks onto the beaches [22,57]. Thus, such high densities of cotton bud sticks and other marine litter items found on the beaches of Cabedelo and Âncora during winter could be explained by exceptional adverse weather conditions prior to sampling coupled with inefficient sewage systems and human behaviour (disposing of these materials in sewage rather than garbage streams).

In 2017, more than 300 tons of plastic were produced globally [62] and it is expected that this amount of plastic will double in the next few decades [63]. A recent study has demonstrated that the presence of plastic can negatively influence the decomposition and nitrogen liberation from the natural wrack to the ecosystem [6]. Moreover, many invertebrates feed on natural wrack, playing a crucial role in the recycling of nutrients in coastal habitats $[64,65]$. On the other hand, some studies proved that wrack consumers can ingest marine plastic litter accumulated on wrack $[66,67]$. Other animals can feed on the wrack consumers $[3,68]$, so the presence of plastics and toxic elements (i.e., cigarette butts) in this natural wrack could also promote cascading effects on the food chain. Thus, urgent management is required to end plastic pollution on the sandy beaches of Northern Portugal and to maintain the healthy functioning of the coastal ecosystems.

Our study also showed as in summer, cigarette butts and other pollutants (mainly formed by leftover food) were also very abundant in the marine litter, probably because of the increased frequency of bathers and the influence of tourism activities. In this area, people visit beaches much more frequently in summer than in winter. While leftover food is easily degradable, cigarette butts are very perdurable in the coastal ecosystems and can cause metal contamination [69]. The north Portuguese coast is very vulnerable to marine litter, since the economy of this area is linked to fishing and tourism activities. The west of the Iberian Peninsula also experiences numerous recreational and maritime activities and is an important route for commercial vessels and cruise ships, thus adding increased sources of pollution to coastal ecosystems in the form of marine litter. The total amount of marine litter found on the beaches of northern Portugal was somewhat higher compared to other places of the west of the Iberian Peninsula, such as Cádiz [57], Galicia [41], Madeira [56], and Açores [42,55,70], but was much lower than that found in other highly polluted areas such as Papua (New Guinea [71]), Rio de Janeiro (Brazil, [72]) or Chile [73]. The high marine litter pollution found on the sandy beaches in this study, which are located far away from urban centres where tourists and local bathers are rare, provides some evidence for the urgent need to manage and control this problem in the North of Portugal.

Until now, research of marine litter in Portugal have been focused on quantifying the items of small size such as microplastics [74,75] and have done on the deepest areas of the sea [76-78]. In addition, the quantification of natural wrack diversity has been never studied on the north Portuguese coast. Therefore, our study provides the first assessment of wrack and marine litter depositions on the sandy beaches in the North of Portugal and shows that marine litter depositions considerably exceed the amounts of natural wrack found upon beaches. This fact could have serious consequences by altering the ecological services of the natural wrack, for example, limiting the cycle of nutrients on the beaches [6]. In addition, the northern Portugal sandy beaches showed a greater amount of marine litter than other north Atlantic beaches, which could have negative social and economic implications. This study suggests that beach morphodynamics and meteorological conditions can play a very important role in the spatio-temporal variability of the natural wrack and marine litter accumulations. Thus, future research should consider this spatio-temporal variability when quantifying marine litter and wrack on sandy beaches. These findings are essential to the future design of management plan strategies that effectively remove marine litter on beaches. 
Supplementary Materials: The following are available online at http://www.mdpi.com/2077-1312/8/12/966/s1, Figure S1: Beaches profiles. Table S1: Sediment characteristics. Table S2: Two-way ANOVA results. Table S3: Macroalgae taxa and marine litter OSPAR categories of the natural wrack and marine litter.

Author Contributions: Conceptualisation, L.G.-M., P.V. and M.R.; methodology, L.G.-M. and M.R.; formal analysis, P.V. and M.R.; investigation, L.G.-M., P.V. and M.R.; resources, M.R. and P.V.; data curation, M.R. and P.V.; writing - original draft preparation, L.G.-M.; writing—review and editing, L.G.-M., P.V. and M.R.; supervision, M.R.; project administration, M.R.; funding acquisition, M.R. All authors have read and agreed to the published version of the manuscript.

Funding: This research was funded by FCT Strategic Funding “UID/Multi/04423/2019”.

Acknowledgments: This research was developed under Project No. 029818, co-financed by COMPETE 2020, Portugal 2020 and the European Union through the ERDF, and by FCT through national funds. This study was partially funded by the FCT Strategic Funding UID/Multi/04423/2019. We want to thank the useful comments from three anonymous reviewers greatly improved the quality of this manuscript.

Conflicts of Interest: The authors declare no conflict of interest.

\section{References}

1. Bustamante, R.H.; Branch, G.M.; Eekhout, S. Maintenance of an exceptional intertidal grazer biomass in South Africa: Subsidy by Subtidal Kelps. Ecology 1995, 76, 2314-2329. [CrossRef]

2. Duggins, D.O.; Simenstad, C.A.; Estes, J.A. Magnification of secondary production by kelp detritus in coastal marine ecosystems. Science 1989, 245, 170-173. [CrossRef] [PubMed]

3. Dugan, J.E.; Hubbard, D.M.; McCrary, M.D.; Pierson, M.O. The response of macrofauna communities and shorebirds to macrophyte wrack subsidies on exposed sandy beaches of southern California. Estuar. Coast. Shelf Sci. 2003, 58, 25-40. [CrossRef]

4. Lastra, M.; Rodil, I.F.; Sánchez-Mata, A.; García-Gallego, M.; Mora, J. Fate and processing of macroalgal wrack subsidies in beaches of Deception Island, Antarctic Peninsula. J. Sea Res. 2014, 88, 1-10. [CrossRef]

5. Battisti, C.; Fanelli, G.; Filpa, A.; Cerfolli, F. Giant Reed (Arundo donax) wrack as sink for plastic beach litter: First evidence and implication. Mar. Pollut. Bull. 2020, 155, 111179. [CrossRef]

6. Litchfield, S.G.; Schulz, K.G.; Kelaher, B.P. The influence of plastic pollution and ocean change on detrital decomposition. Mar. Pollut. Bull. 2020, 158. [CrossRef]

7. UNEP/MAP Assessment of the Status of Marine Litter, in the Mediterranean; UNEP/Earthprint: Athens, Grece, 2011.

8. Barboza, L.G.A.; Cózar, A.; Gimenez, B.C.G.; Barros, T.L.; Kershaw, P.J.; Guilhermino, L. Macroplastics Pollution in the Marine Environment, 2nd ed.; Elsevier Ltd.: Amsterdam, The Netherlands, 2018; ISBN 9780128050521.

9. Barnes, D.K.A.; Galgani, F.; Thompson, R.C.; Barlaz, M. Accumulation and fragmentation of plastic debris in global environments. Philos. Trans. R. Soc. B Biol. Sci. 2009, 364, 1985-1998. [CrossRef]

10. Van Cauwenberghe, L.; Devriese, L.; Galgani, F.; Robbens, J.; Janssen, C.R. Microplastics in sediments: A review of techniques, occurrence and effects. Mar. Environ. Res. 2015, 111, 5-17. [CrossRef]

11. Alomar, C.; Estarellas, F.; Deudero, S. Microplastics in the Mediterranean sea: Deposition in coastal shallow sediments, spatial variation and preferential grain size. Mar. Environ. Res. 2016, 115, 1-10. [CrossRef]

12. Williams, A.; Tudor, D. Litter burial and exhumation: Spatial and temporal distribution on a cobble pocket beach. Mar. Pollut. Bull. 2001, 42, 1031-1039. [CrossRef]

13. Kusui, T.; Noda, M. International survey on the distribution of stranded and buried litter on beaches along the Sea of Japan. Mar. Pollut. Bull. 2003, 47, 175-179. [CrossRef]

14. Kühn, S.; Bravo Rebolledo , E.L.; van Franeker, J.A. Deleterious effects of litter on marine life. In Marine Anthropogenic Litter; Bergmann, M., Gutow, L., Klages, M., Eds.; Springer: Cham, Switzerland, 2015; pp. 75-116.

15. Gall, S.C.; Thompson, R.C. The impact of debris on marine life. Mar. Pollut. Bull. 2015, 92, $170-179$. [CrossRef] [PubMed]

16. Molnar, J.L.; Gamboa, R.L.; Revenga, C.; Spalding, M.D. Assessing the global threat of invasive species to marine biodiversity. Front. Ecol. Environ. 2008, 6, 485-492. [CrossRef]

17. United Nations Integrated Monitoring and Assessment Guidance. In United Nations Environment Programme Mediterranean Action Plan, Proceedings of the 19th Ordinary Meeting of the Contracting Parties to the Convention for the Protection of the Marine Environment and the Coastal Region of the Mediterranean and Its Protocols, Athens, Greece, 9-12 February 2016; UNEP: Nairobi, Kenya, 2016; pp. 93-94. 
18. Papadopoulou, N. Seabed marine litter, comparison of 4 Aegean trawling grounds. In Proceedings of the 11th Panhellenic Symposium on Oceanography and Fisheries, Mytilene, Greece, 13-17 May 2015; pp. 2013-2016.

19. Cheshire, A.; Adler, E.; Barbière, J.; Cohen, Y.; Evans, S.; Jarayabhand, S.; Jeftic, Lj.; Jung, R.-T.; Kinsey, S.; Kusui, T.; et al. UNEP/IOC Guidelines on Survey and Monitoring of Marine Litter. In UNEP Regional Seas Reports and Studies, No. 186; IOC Technical Series No. 83; UNEP: Nairobi, Kenya, 2009; pp. 5-8.

20. GESAMP Guidelines for the monitoring and assessment of plastic litter in the ocean. Rep. Stud. 2019, 99, 130.

21. Chubarenko, I.; Stepanova, N. Microplastics in sea coastal zone: Lessons learned from the Baltic amber. Environ. Pollut. 2017, 224, 243-254. [CrossRef] [PubMed]

22. Poeta, G.; Conti, L.; Malavasi, M.; Battisti, C.; Acosta, A.T.R. Beach litter occurrence in sandy littorals: The potential role of urban areas, rivers and beach users in central Italy. Estuar. Coast. Shelf Sci. 2016, 181, 231-237. [CrossRef]

23. Thiel, M.; Hinojosa, I.A.; Miranda, L.; Pantoja, J.F.; Rivadeneira, M.M.; Vásquez, N. Anthropogenic marine debris in the coastal environment: A multi-year comparison between coastal waters and local shores. Mar. Pollut. Bull. 2013, 71, 307-316. [CrossRef]

24. Fox, S.E.; Stieve, E.; Valiela, I.; Hauxwell, J.; McClelland, J. Macrophyte abundance in Waquoit Bay: Effects of land-derived nitrogen loads on seasonal and multi-year biomass patterns. Estuar. Coast. 2008, 31, 532-541. [CrossRef]

25. Ochieng, C.A.; Erftemeijer, P.L.A. Accumulation of seagrass beach cast along the Kenyan coast: A quantitative assessment. Aquat. Bot. 1999, 65, 221-238. [CrossRef]

26. Piriz, M.L.; Eyras, M.C.; Rostagno, C.M. Changes in biomass and botanical composition of beach-cast seaweeds in a disturbed coastal area from Argentine Patagonia. J. Appl. Phycol. 2003, 15, 67-74. [CrossRef]

27. Sousa-Dias, A.; Melo, R.A. Long-term abundance patterns of macroalgae in relation to environmental variables in the Tagus Estuary (Portugal). Estuar. Coast. Shelf Sci. 2008, 76, 21-28. [CrossRef]

28. Baring, R.J.; Fairweather, P.G.; Lester, R.E. Nearshore drift dynamics of natural versus artificial seagrass wrack. Estuar. Coast.Shelf Sci. 2018, 202, 164-171. [CrossRef]

29. McLachlan, A.; Brown, A. Ecology of Sandy Shores; Academic Press: Burlington, MA, USA, 2006.

30. Orr, M.; Zimmer, M.; Jelinski, D.E.; Mews, M. Wrack deposition on different beach types: Spatial and temporal variation in the pattern of subsidy. Ecology 2005, 86, 1496-1507. [CrossRef]

31. OSPAR Guideline for monitoring marine litter on the beachs in the OSPAR Maritime Area. OSPAR Comm. 2010, $1,84$.

32. Emery, K.O. A simple method of measuring beach profiles. Limnol. Oceanogr. 1961, 6, 90-93. [CrossRef]

33. Underwood, A.J. Experiments in Ecology: Their Logical Design and Interpretation Using Analysis of Variance; Cambridge University Press: Cambridge, UK, 1996.

34. Anderson, M.J. A new method for non-parametric multivariate analysis of variance. Austral Ecol. 2001, 26, 32-46. [CrossRef]

35. Anderson, M.J. Distance-based tests for homogeneity of multivariate dispersions. Biometrics 2006, 62, $245-253$. [CrossRef]

36. Clarke, K.R. Non-parametric multivariate analyses of changes in community structure. Austral Ecol. 1993, 18, 117-143. [CrossRef]

37. Somerfield, P.; Clarke, K. Taxonomic levels, in marine community studies, revisited. Mar. Ecol. Prog. Ser. 1995, 127, 113-119. [CrossRef]

38. Olsgard, F.; Somerfield, P.; Carr, M. Relationships between taxonomic resolution and data transformations in analyses of a macrobenthic community along an established pollution gradient. Mar. Ecol. Prog. Ser. 1997, 149, 173-181. [CrossRef]

39. Mews, M.; Zimmer, M.; Jelinski, D. Species-specific decomposition rates of beach-cast wrack in Barkley Sound, British Columbia, Canada. Mar. Ecol. Prog. Ser. 2006, 328, 155-160. [CrossRef]

40. Hammer, J.; Kraak, M.H.S.; Parsons, J.R. Plastics in the Marine Environment: The Dark Side of a Modern Gift; Springer: New York, NY, USA, 2012; pp. 1-44.

41. Gago, J.; Lahuerta, F.; Antelo, P. Characteristics (abundance, type and origin) of beach litter on the Galician coast (NW Spain) from 2001 to 2010. Sci. Mar. 2014, 78, 125-134. [CrossRef]

42. Pieper, C.; Ventura, M.A.; Martins, A.; Cunha, R.T. Beach debris in the Azores (NE Atlantic): Faial Island as a first case study. Mar. Pollut. Bull. 2015, 101, 575-582. [CrossRef] [PubMed] 
43. Biskup, S.; Bertocci, I.; Arenas, F.; Tuya, F. Functional responses of juvenile kelps, Laminaria ochroleuca and Saccorhiza polyschides, to increasing temperatures. Aquat. Bot. 2014, 113, 117-122. [CrossRef]

44. Ferreira, J.G.; Ramos, L. A model for the estimation of annual production rates of macrophyte algae. Aquat. Bot. 1989, 33, 53-70. [CrossRef]

45. Solidoro, C.; Brando, V.; Dejak, C.; Franco, D.; Pastres, R.; Pecenik, G. Long term simulations of population dynamics of Ulvar. in the lagoon of Venice. Ecol. Model. 1997, 102, 259-272. [CrossRef]

46. Plus, M.; Auby, I.; Verlaque, M.; Levavasseur, G. Seasonal variations in photosynthetic irradiance response curves of macrophytes from a Mediterranean coastal lagoon. Aquat. Bot. 2005, 81, 157-173. [CrossRef]

47. Pedersen, M.; Borum, J. Nutrient control of algal growth in estuarine waters. Nutrient limitation and the importance of nitrogen requirements and nitrogen storage among phytoplankton and species of macroalgae. Mar. Ecol. Prog. Ser. 1996, 142, 261-272. [CrossRef]

48. Fernández, C. The retreat of large brown seaweeds on the north coast of Spain: The case of Saccorhiza polyschides. Eur. J. Phycol. 2011, 46, 352-360. [CrossRef]

49. Martínez, B.; Pato, L.S.; Rico, J.M. Nutrient uptake and growth responses of three intertidal macroalgae with perennial, opportunistic and summer-annual strategies. Aquat. Bot. 2012, 96, 14-22. [CrossRef]

50. Barreiro, F.; Gómez, M.; Lastra, M.; López, J.; De La Huz, R. Annual cycle of wrack supply to sandy beaches: Effect of the physical environment. Mar. Ecol. Prog. Ser. 2011, 433, 65-74. [CrossRef]

51. Barreiro, F.; Gómez, M.; López, J.; Lastra, M.; de la Huz, R. Coupling between macroalgal inputs and nutrients outcrop in exposed sandy beaches. Hydrobiologia 2013, 700, 73-84. [CrossRef]

52. Gómez, M.; Barreiro, F.; López, J.; Lastra, M.; de la Huz, R. Deposition patterns of algal wrack species on estuarine beaches. Aquat. Bot. 2013, 105, 25-33. [CrossRef]

53. Olabarria, C.; Lastra, M.; Garrido, J. Succession of macrofauna on macroalgal wrack of an exposed sandy beach: Effects of patch size and site. Mar. Environ. Res. 2007, 63, 19-40. [CrossRef]

54. Arenas, F.; Fernández, C. Size structure and dynamics in a population of Sargassum muticum (Phaeophyceae). J. Phycol. 2000, 36, 1012-1020. [CrossRef]

55. Ríos, N.; Frias, J.P.G.L.; Rodríguez, Y.; Carriço, R.; Garcia, S.M.; Juliano, M.; Pham, C.K. Spatio-temporal variability of beached macro-litter on remote islands of the North Atlantic. Mar. Pollut. Bull. 2018, 133, 304-311. [CrossRef]

56. Álvarez, S.; Gestoso, I.; Herrera, A.; Riera, L.; Canning-Clode, J. A comprehensive first baseline for marine litter characterization in the Madeira Archipelago (NE Atlantic). Water Air Soil Pollut. 2020, 231. [CrossRef]

57. Asensio-Montesinos, F.; Anfuso, G.; Ramírez, M.O.; Smolka, R.; Sanabria, J.G.; Enríquez, A.F.; Arenas, P.; Bedoya, A.M. Beach litter composition and distribution on the Atlantic coast of Cádiz (SW Spain). Reg. Stud. Mar. Sci. 2020, 34, 101050. [CrossRef]

58. Dau, B.K.; Gilardi, K.V.K.; Gulland, F.M.; Higgins, A.; Holcomb, J.B.; Leger, J.S.; Ziccardi, M.H. Fishing gear-related injury in california marine wildlife. J. Wildl. Dis. 2009, 45, 355-362. [CrossRef]

59. Thiel, M.; Bravo, M.; Hinojosa, I.A.; Luna, G.; Miranda, L.; Núñez, P.; Pacheco, A.S.; Vásquez, N. Anthropogenic litter in the SE Pacific: An overview of the problem and possible solutions. Revista de Gestão Costeira Integrada 2011, 11, 115-134. [CrossRef]

60. Williams, A.T.; Pond, K.; Ergin, A.; Cullis, M.J. The Hazards of Beach Litter; Springer: Dordrecht, The Netherlands, 2013; pp. 753-780.

61. Cole, M.; Lindeque, P.; Halsband, C.; Galloway, T.S. Microplastics as contaminants in the marine environment: A review. Mar. Pollut. Bull. 2011, 62, 2588-2597. [CrossRef] [PubMed]

62. PlasticsEurope. Plastics - The Facts 2017. An Analysis of European Plastics Production, Demand and Waste Data; Plastics Europe: Wemmel, Belgium, 2018.

63. Geyer, R.; Jambeck, J.R.; Law, K.L. Production, use, and fate of all plastics ever made. Sci. Adv. 2017, 3, e1700782. [CrossRef] [PubMed]

64. Dugan, J.E.; Hubbard, D.M.; Page, H.M.; Schimel, J.P. Marine macrophyte wrack inputs and dissolved nutrients in beach sands. Estuaries Coasts 2011, 34, 839-850. [CrossRef]

65. Taylor, S.; Bishop, M.; Kelaher, B.; Glasby, T. Impacts of detritus from the invasive alga Caulerpa taxifolia on a soft sediment community. Mar. Ecol. Prog. Ser. 2010, 420, 73-81. [CrossRef]

66. Ugolini, A.; Ungherese, G.; Ciofini, M.; Lapucci, A.; Camaiti, M. Microplastic debris in sandhoppers. Estuar. Coast. Shelf Sci. 2013, 129, 19-22. [CrossRef] 
67. Iannilli, V.; Di Gennaro, A.; Lecce, F.; Sighicelli, M.; Falconieri, M.; Pietrelli, L.; Poeta, G.; Battisti, C. Microplastics in Talitrus saltator (Crustacea, Amphipoda): New evidence of ingestion from natural contexts. Environ. Sci. Pollut. Res. 2018, 25, 28725-28729. [CrossRef]

68. Ince, R.; Hyndes, G.A.; Lavery, P.S.; Vanderklift, M.A. Marine macrophytes directly enhance abundances of sandy beach fauna through provision of food and habitat. Estuar. Coast. Shelf Sci. 2007, 74, 77-86. [CrossRef]

69. Moerman, J.W.; Potts, G.E. Analysis of metals leached from smoked cigarette litter. Tob. Control 2011, 20, i30-i35. [CrossRef]

70. Monteiro, R.C.P.; Ivar do Sul, J.A.; Costa, M.F. Plastic pollution in islands of the Atlantic Ocean. Environ. Pollut. 2018, 238, 103-110. [CrossRef]

71. Smith, S.D.A. Marine debris: A proximate threat to marine sustainability in Bootless Bay, Papua New Guinea. Mar. Pollut. Bull. 2012, 64, 1880-1883. [CrossRef]

72. Oigman-Pszczol, S.S.; Creed, J.C. Quantification and classification of marine litter on beaches along Armação dos Búzios, Rio de Janeiro, Brazil. J. Coast. Res. 2007, 23, 421-428. [CrossRef]

73. Bravo, M.; de los Ángeles Gallardo, M.; Luna-Jorquera, G.; Núñez, P.; Vásquez, N.; Thiel, M. Anthropogenic debris on beaches in the SE Pacific (Chile): Results from a national survey supported by volunteers. Mar. Pollut. Bull. 2009, 58, 1718-1726. [CrossRef] [PubMed]

74. Rodrigues, M.O.; Abrantes, N.; Gonçalves, F.J.M.; Nogueira, H.; Marques, J.C.; Gonçalves, A.M.M. Spatial and temporal distribution of microplastics in water and sediments of a freshwater system (Antuã River, Portugal). Sci. Total Environ. 2018, 633, 1549-1559. [CrossRef] [PubMed]

75. Frias, J.P.G.L.; Gago, J.; Otero, V.; Sobral, P. Microplastics in coastal sediments from Southern Portuguese shelf waters. Mar. Environ. Res. 2016, 114, 24-30. [CrossRef]

76. Oliveira, F.; Monteiro, P.; Bentes, L.; Henriques, N.S.; Aguilar, R.; Gonçalves, J.M.S. Marine litter in the upper São Vicente submarine canyon (SW Portugal): Abundance, distribution, composition and fauna interactions. Mar. Pollut. Bull. 2015, 97, 401-407. [CrossRef]

77. Neves, D.; Sobral, P.; Pereira, T. Marine litter in bottom trawls off the Portuguese coast. Mar. Pollut. Bull. 2015, 99, 301-304. [CrossRef]

78. Rodríguez, Y.; Pham, C.K. Marine litter on the seafloor of the Faial-Pico Passage, Azores Archipelago. Mar. Pollut. Bull. 2017, 116, 448-453. [CrossRef]

Publisher's Note: MDPI stays neutral with regard to jurisdictional claims in published maps and institutional affiliations.

(C) 2020 by the authors. Licensee MDPI, Basel, Switzerland. This article is an open access article distributed under the terms and conditions of the Creative Commons Attribution (CC BY) license (http://creativecommons.org/licenses/by/4.0/). 